\title{
Drought and salinity stress management for higher and sustainable canola (Brassica napus L.) production: a critical review
}

\author{
Ayman EL Sabagh ${ }^{1^{*}}$, Akbar Hossain $^{2}$, Celaleddin Barutçular ${ }^{3}$, Mohammad Sohidul Islam $^{4}$, Disna Ratnasekera ${ }^{5}$, \\ Narendra Kumar ${ }^{6}$, Ram Swaroop Meena ${ }^{7}$, Hany Sobhy Gharib ${ }^{1}$, Hirofumi Saneoka ${ }^{8}$, Jaime A. Teixeira da \\ Silva ${ }^{9}$
}

${ }^{1}$ Department of Agronomy, Faculty of Agriculture, Kafrelsheikh University, 33156 Kafrelsheikh, Egypt

${ }^{2}$ Wheat Research Center, Bangladesh Agricultural Research Institute, Nashipur, Dinajpur, 5200, Bangladesh

${ }^{3}$ Department of Field Crops, Faculty of Agriculture, Çukurova University, 01330 Adana, Turkey

${ }^{4}$ Department of Agronomy, Hajee Mohammad Danesh Science and Technology University, Bangladesh

${ }^{5}$ Department of Agricultural Biology, Faculty of Agriculture, University of Ruhuna, 81100, Sri Lanka

${ }^{6}$ Indian Council of Agricultural Research (ICAR), Indian Institute of Pulses Research, Kanpur - 208 024, India

${ }^{7}$ Department of Agronomy, Institute of Agricultural Sciences, Banaras Hindu University, Varanasi-221005, Uttar

Pradesh, India

${ }^{8}$ Plant Nutritional Physiology Laboratory, Graduate School of Biosphere Science, Hiroshima University, 1-7-1

Kagamiyama, Higashi-Hiroshima, Hiroshima 739-8521, Japan

${ }_{9}^{9}$ Independent researcher, P. O. Box 7, Miki-cho post office, Ikenobe 3011-2, Kagawa-ken, 761-0799, Japan

*Corresponding authors: ayman.elsabagh@agr.kfs.edu.eg (A. El Sabagh); tanjimar2003@yahoo.com (A. Hossain)

\section{Abstract}

The oil of canola (Brassica napus L.), a globally important major oilseed crop, is used for salads, frying, the development of margarines, shortenings, and other food products. However, the growth and yield of canola are mainly restricted by drought and salinity, which can become acute in climate change. The exogenous application of some antioxidants has been shown to enhance tolerance to drought and salinity in select plants. Therefore, a thorough understanding of the effect of drought and salinity stress is crucial for understanding their adverse effect on canola cultivation and to establish useful strategies to maximize oil productivity. Given the economic importance of this crop, we reviewed studies within the extensive canola literature to assess the adverse effects of abiotic stresses, with a special emphasis on drought, water deficit and salinity, and how these stresses impact its growth and productivity in a bid to determine the role that antioxidants might play in alleviating the adverse effects of environmental stresses. This review notes how the productivity of canola tends to decrease under different abiotic stresses due to their adverse effect on morphological, physiological and biochemical processes, including lowered or reduced leaf area, leaf relative water content, stability of cell membranes, photosynthetic capacity, stomatal conductance, damage to chlorophyll and the production of reactive oxygen species. In addition, this review also discusses management strategies that would allow researchers or farmers to mitigate salinity and drought stress by using compatible solutes, nutrient management or other means to maximize canola yield. The application of antioxidants to soil, in combination with essential nutrients, alongside other management strategies, may assist in alleviating the harmful effects of environmental stresses in canola production.

Keywords: Antioxidants; Adverse effects; Canola; Drought; Salinity stress; Yield.

Abbreviations: AsA_ascorbic acid; chl a_chlorophyll $a$; chl b_chlorophyll $b$; GB_glycine betaine; MDA_malondialdehyde; RLWC_relative leaf water content; ROS_reactive oxygen species; RWC_relative water content; SA_salicylic acid.

Nutritional importance and other uses of canola

Canola, a sub-group of Brassica napus L., also known as oilseed rape, is a major oilseed crop and was globally ranked third in terms of production among oilseed crops (Johnston et al., 2002; Ashraf and McNeilly, 2004). Canola seeds contain $25 \%$ protein and $40-42 \%$ oil, $60 \%$ oleic acid and $8.8 \%$ linoleic acid ( $\mathrm{Hu}$ et al., 2006), and $20-30 \%$ stearate in transgenic canola seeds (Hawkins and Kridl, 1998). Canola oil is used for salads and frying, as well as to develop margarines, shortenings, and other food products (de Oliveira et al., 2015). High contents of erucic acid (Food Standards Australia New Zealand, 2003) and glucosinolates (Cartea and Velasco, 2008) can be toxic to humans and animals. Canola seeds have a low erucic acid (26\%) and glucosinolate (49\%) content (Knutsen et al., 2016). In canola, protein and oil content is affected by the level of erucic acid and glucosinolate (Shi et al., 2011). The European Food Safety Authority established in 
2016 a tolerable daily intake of $7 \mathrm{mg} \mathrm{kg}^{-1}$ body weight (bw) day $^{-1}$ for erucic acid based on the lack of any observed adverse effect of $0.7 \mathrm{~g} \mathrm{~kg}^{-1}$ bw day ${ }^{-1}$ on lipidosis in young rats and newborn piglets (Knutsen et al., 2016). The safety limit of consumption of erucic acid in oil used to be $<2 \%$ and $<30$ $\mu \mathrm{mol} \mathrm{g}^{-1}$ of glucosinolate in oil-free meals (Nelson and Grombacher, 1992). In humans, almost all erucic acid is absorbed from the digestive tract (Bézard et al., 1994).

The World Health Organization (WHO) estimates that globally, cardiovascular diseases account for the deaths of 17.7 million people annually, or $31 \%$ of all deaths (WHO, 2017). Canola oil helps to lower cholesterol in humans since it is rich in two healthy essential fatty acids, linoleic acid ( $\omega-6$ fatty acid) and $\alpha$-linolenic acid ( $\omega-3$ fatty acid) in a 2:1 ratio, which is nutritionally ideal, and low levels of unhealthy fatty acids (CCC, 2017a). Thus, canola may play an important role in nutritional security in the developing world, explaining its increasing demand from and consumption by diet-conscious consumers (Namvar and Khandan, 2015). Additionally, the residue left after oil extraction is rich in protein and can be used for animal feed (Din et al., 2011: Dawood and Sadak, 2014). Canola can also serve as a catch crop as it is able to absorb high levels of nitrate from the soil, thus reducing nitrogen leaching in autumn and winter (Malagoli et al., 2005).

\section{Abiotic stresses reduce crop productivity}

Crop productivity can decrease due to the adverse effects of different abiotic stresses, including salinity (Paulsen, 1994) and drought (Zirgoli and Kahrizi, 2015). However, since abiotic stresses are unpredictable, the best way to cope with them is to develop tolerant varieties that perform well under stress as well as under optimum environmental conditions, a strategy that has worked well in wheat (Nouri et al., 2011; Hossain and Teixeira da Silva, 2012, 2013). However, the development of cultivars that are tolerant to abiotic stresses is a time-consuming process. Enhancing a plant's tolerance to drought and salinity is thus a viable approach to resolving the challenge of abiotic stress tolerance in arid and semi-arid environments, at least in wheat (Talebi, 2009).

Hossain et al. (2012) found that high temperature during drought is a key constraint for the growth and productivity of spring rain-fed wheat and barley, ultimately caused by a deficit in soil moisture and low relative humidity. Drought stress affects plant growth by reducing nutrient uptake and impairs the active transport of photosynthates ( $\mathrm{Hu}$ and Schmidhalter, 2005; Jaleel et al., 2009). Nutrient deficiency is even observed in fertilized fields due to a reduced rate of diffusion of nutrients from the soil matrix to the root surface and translocation to sites of photosynthesis in maize leaves (Hu et al., 2007). Hu and Schmidhalter (2005) and Silva et al. (2011) indicated that reduced plant growth under drought stress might be due to reduced nutrient uptake and transport from roots to the shoot due to restricted transpiration rates, impaired active transport, and membrane permeability. Umar (2006) noticed that the nutrient film around soil particles became thin under drought stress, thereby increasing the distance by which ions had to move, resulting in poor diffusion of ions into plant roots in sorghum, mustard and groundnut. In common bean and flax, the relative level of photosynthates depends on soil moisture supply to plants (Chikov et al., 2001).
Salt and osmotic stresses inhibit or delay cowpea and wheat seed germination and seedling establishment (Almansouri et al., 2001; El-Shaieny, 2015). Salt stress negatively affects plant growth via oxidative stress, especially ion toxicity, nutritional and hormonal imbalance, and osmotic stress (Parida and Das, 2005; Ashraf, 2009). In addition, salt stress degrades pigments such as chlorophyll (chl), but the level depends on the level of tolerance of the cultivar to the salt, the enzymes involved in photosynthesis such as Rubisco show lower activity, while reduced photosynthetic ability is caused by damage to photosystem II (Ashraf and Harris, 2013). The salt-induced degradation of chl starts with the elimination of phytol, which is cause by enhanced chlorophyllase activity (Fang et al., 1998).

\section{Mitigating abiotic stress in plants}

The accumulation of some compatible solutes (proline and sugars) is proportional to the change of external osmotic pressure, and this helps to obtain an ionic balance in vacuoles and cytoplasm inside the cell (Hasegawa et al., 2000), thereby protecting cell structure and supporting continued water influx (Parida and Das, 2005). The exogenous application of osmoprotectants is a shotgun approach to mitigate the negative effects of abiotic stresses, including drought stress (Ashraf and Foolad, 2007). Several organic compatible solutes such as proline take part in plant stress tolerance (Ali and Ashraf, 2011). Proline is found widely in plants and accumulates in large quantities in response to environmental stresses such as drought, salinity, and extreme temperatures (Mattioli, 2009). Proline is correlated with the relief of cellular osmotic stress, detoxification of excess ammonia, stabilization of proteins and/or membranes and enhancing the stability of some cytoplasmic and mitochondrial enzymes (Ozdemir et al., 2004). The exogenous application or excessive production, for example through transgenic plants, of proline may prevent the harmful effects of salt stress by stimulating cell growth, enhancing metabolism, or reducing the oxidation of membrane lipids (Parida and Das, 2005; Szabados and Savouré, 2010).

The exogenous application of glycine betaine (GB), a quaternary ammonium compound, i.e., an amino acid derivative that is an effective solute, improves the growth and tolerance of a wide range of plants under various stress conditions and enhances their survival by regulating a number of physiological and biochemical processes (Ashraf and Foolad, 2007; Aghaei and Komatsu, 2013). GB and proline are organic osmolytes that accumulate in several plant species in response to different stress conditions (Ashraf and Foolad, 2007; Ali and Ashraf, 2011). GB maintains osmotic balance and can also scavenge free radicals generated under abiotic stress, so exogenous foliar application of $\mathrm{GB}$ is a recommended approach to induce stress tolerance in crops (Ashraf and Foolad, 2007). Like GB and proline, some organic acids such as citric acid are osmolytes that can accumulate in halophytic plants in response to saline and alkaline stress (Sun and Hong, 2011).

To counter the deleterious effects caused by the excessive production of reactive oxygen species (ROS), plants scavenge ROS in a mechanism that involves coordination between signaling and metabolic pathways in which enzymatic and non-enzymatic antioxidants act as a defense mechanism to 
regulate the levels of ROS (Mittler, 2002; Suzuki et al., 2012). In a process that uses multiple redox reactions, the active oxygen in ROS is deactivated (Tuteja, 2007; Sharma et al., 2012). Cell membrane damage, which is caused by salinity, can be determined by the rate of formation of a lipid peroxidation product, malondialdehyde (MDA) (Gill and Tuteja, 2010). When the activity of antioxidant enzymes increases, the level of MDA decreases (Sharma et al., 2012). Salt-tolerant plants have lower levels of MDA, which indicates reduced salt-induced injury to membranes (Sairam et al., 2002).

Salicylic acid (SA) is actively involved in various biochemical and physiological mechanisms of plants, and helps them mitigate the adverse effects of water deficit stress (Hayat et al., 2010). SA acts as an antioxidant by increasing the levels of glutathione, which is involved in scavenging ROS, thus SA serves as an important messenger molecule in a plant's response to biotic and abiotic stresses (Herrera-Vásquez et al., 2015). SA impacts stomatal function, chl content, transpiration rate, and respiratory pathways, for example by alleviating the decrease in photosynthetic capacity of grapevine leaves (Wang et al., 2010), so it might possess a physiological role, and would most likely be involved in the regulation of some photosynthetic reactions (Horváth et al., 2007).

The roles of ascorbic acid (AsA), a small, water-soluble antioxidant, in plant growth and other developmental processes are well documented (Pignocchi and Foyer, 2003). AsA acts as a primary substrate in the cyclical pathway to detoxify and neutralize the damaging effect of superoxide radicals and singlet oxygen, which are produced by the Mehler reaction and photorespiration, by adjusting glutathione and different enzymatic antioxidants (Noctor and Foyer, 1998). The removal of free radicals helps AsA to increase stress tolerance and reduce oxidative stress (Shalata and Neumann, 2001). The foliar application of AsA in sunflower increased the rate of photosynthesis by increasing chl content and improved soluble sugar content (Ebrahimian and Bybordi, 2012).

Considering these broad issues underlying abiotic stresses in plants, and their mitigation, this review attempts to assess some of the adverse effects of abiotic stresses on canola, with special reference to drought, water deficit and salinity, and to determine the possible role that antioxidants or other additives, as well as agronomic practices, may have in alleviating these stresses.

\section{Drought, water and salinity stress adversely affect canola}

\section{Effect of drought stress on canola growth and productivity}

Drought is one of the most important abiotic constraints that restricts the growth and yield of crop plants by influencing physiological and biochemical processes. Drought, as a result of low soil water content, results in increased salinity, which limits nutrient supply, so drought and salinity stress often cause stress in plants concomitantly (Hu and Schmidhalter, 2005). The major common undesirable impact of drought and salinity on canola is a decrease in yield-related attributes as well as a decline in the quality of seed and oil (Zamani et al., 2010). For example, Jensen et al. (1996) found that the application of early or late drought reduced seed yield by $8 \%$ and $17 \%$, respectively. This is because salinity lowers oil and linoleic acid contents, but increases glucosinalate and stearic acid contents (Moghadam et al., 2011). However, during stress, canola plants produce different organic solutes that allow them to survive under adverse conditions by improving their physiology (Zahedi and Moghdam, 2011). Yield decreased in drought-stressed canola plants that accumulated glucosinolate at the flowering stage (Bouchereau et al., 1996).

When drought affects the reproductive stages (flowering to pod development stage) of canola, final yield is significantly reduced since pod formation and seed size are hindered, resulting in fewer siliques per plant and seeds per silique, ultimately resulting in lower economic yield, as assessed by lower grain yield and oil yield per unit production area (Ghobadi et al., 2006). Gan et al. (2004), in canola and mustard, and Sinaki et al. (2007) in canola, showed that drought stress induced flower and fruit drop, finally reducing overall production. Canola seed yield can be reduced, even by a short period of soil moisture stress, during reproductive stages (Ahmadi and Bahrani, 2009). For example, drought stress applied at the anthesis stage in four canola cultivars reduced leaf relative water content $\left(R W C_{\text {leaf }}\right)$ and stomatal conductance, eventually reducing yield, as assessed by number of pods per plant and number of grains per pod (Jamshidi Zinab et al., 2015). Moaveni et al. (2010) found that drought stress significantly reduced oil yield, grain yield, 1000-grain weight, number of siliques per plant and number of grains per silique. Similarly, Shirani Rad and Zandi (2012) found that plant height, number of branches or siliques per plant, number of seeds per silique, 1000-seed weight, seed, biological, and oil yields, oil content, but not harvest index, were significantly reduced by drought stress. Plant reproductive organs or seeds acquire or store resources from the vegetative parts of the plant in canola, thus reduced water uptake finally results in poor silique and seed formation (Ghobadi et al., 2006).

\section{Effect of water stress and soil water deficit on canola growth and productivity}

Morrison and Stewart (2002), Hassanzadeh et al. (2005), Rahnema and Bakhshandeh (2006), Nasri et al. (2008), Tesfamariam et al. (2010), Zakerin et al. (2014), EL Sabagh et al. (2017) and Kandil et al. (2017) found that under water deficit stress, yield and yield components of canola were significantly negatively affected, as indicated by a reduced number of siliques per plant, plant height, plant weight, as well as a number of other physiological parameters in the vegetative stage that had a direct negative impact on the vegetative stage (fewer flowers, smaller seed), a common phenomenon among crop plants and forage species (Martiniello and Teixeira da Silva, 2011), ultimately reducing seed and oil yield. A reduction in water use efficiency can reduce grain yield by as much as circa $30-60 \%$ in canola, depending on the genotype (Mousavi et al., 2010).

$\mathrm{RWC}_{\text {leaf }}$ is an essential physiological parameter to measure drought stress tolerance in plants (Sánchez-Blanco et al., 2002). RWC leaf, osmotic potential, and leaf temperature in canola and mustard were also adversely influenced by drought stress (Fanaei et al., 2009). As much as $48 \%$ of $\mathrm{RWC}_{\text {leaf }}$ in canola was lost under water stress (Sharma et al., 1992). Under water stress, an increase in the concentration of cell electrolytes disturbs the normal metabolic function of 
cell organelles (Mahajan and Tuteja, 2005). Similarly, cell turgidity, as well as the growth of cells and tissues, are adversely affected by water stress, as a result of cell collapse, as was observed in cyclamen (Oertli, 1986) and sunflower (Benlloch-González et al., 2015).

In canola, Gibon et al. (2000) noticed that drought stress significantly reduced chl content, but only between - 0.1 $\mathrm{MPa}$ and - 3.0 MPa, when proline content peaked. Din et al. (2011) also found, in canola, that drought stress significantly reduced chl content by an average of $24 \%$, and ranging between $13 \%$ and $45 \%$, depending on the cultivar, while proline accumulated as much as $81 \%$ and $59 \%$ at the flower initiation and pod-filling stages, respectively. In canola, water stress significantly decreased chl $(a+b)$ content in the vegetative, flowering and $50 \%$ pod-formation stages (Sharma et al., 1992). Water deficit significantly reduced chl content and $\mathrm{RWC}_{\text {leaf }}$ by about 25-30\% (EL Sabagh et al., 2017). Reduced leaf chl content in response to water stress is caused by ROS production, which damages the chloroplasts (Gill and Tuteja, 2010).

The ultimate effect of water deficit on canola is a reduction in plant height, number of branches, pod length, grain size (1000-grain weight) and yield and thus a deterioration of product quality, i.e., reduced oil yield by about $40 \%$ (Istanbulluoglu et al., 2010). Canola is most sensitive to water stress during the flowering stage and least sensitive during the vegetative and seed-filling stages, with the former resulting in crop maturation 127 days early, reduced water use efficiency, seed and oil yield, and oil content (Tesfamariam et al., 2010).

\section{Effect of salinity stress on canola growth and productivity}

Similar to drought stress, soil salinity is also a major abiotic stress that decreases the productivity of crops worldwide (Yamaguchi and Blumwald, 2005). When exposed to salt stress, the growth and development of many plant species, including Brassica species, is negatively affected by limiting physiological, biochemical and metabolic processes as a result of osmotic stress, ion toxicity, and reduced water and mineral availability (Hasegawa et al., 2000).

In Brassica spp., salinity reduced the levels of nutrients ( $\mathrm{Fe}$, $\mathrm{Mn}, \mathrm{Zn}$ ) in leaves, stems and roots at flowering and pod stages (Chakraborty et al., 2016). Reduced plant height caused by saline stress is caused by reduced osmotic and leaf water potential, and increased electrolyte leakage (Dolatabadi and Toorchi, 2017). Salt stress negatively impacted canola seed germination (Mahmoodzadeh, 2008), radicle and plumule length and seedling fresh weight (Bybordi and Tabatabaei, 2009; Bybordi, 2010a), reduced biomass (Bybordi, 2010b), inhibited the seed-filling phase, reduced the number of seeds per pod, number of pods per plant, pod length and plant height (Zamani et al., 2010; Mohammadi et al., 2012), formed fewer leaves, branches, flowers, siliques, shorter siliques, and fewer seed per silique and 1000-seed weight (Mahmoodzadeh, 2008), reduced leaf size and nutrient absorption levels of leaves (Shainberg and Shalhevet, 2012), reduced root, hypocotyl and leaf growth in seedlings with a concomitant rise in IAA oxidase and peroxidase activity (Bybordi et al., 2010a), reduced chl $a$, chl $b$ and total chl content (Nazarbeygi et al., 2011; Bahrani, 2013), reduced total fatty acids by $25 \%$ (Bybordi et al., 2010b), reduced dry matter, plant height, seed yield and 1000-seed weight (Shabani et al., 2013), and reduced root length, seedling fresh weight, seedling dry weight, RWC, ion leakage and chl content in seedlings of five cowpea cultivars (El-Shaieny, 2015). The decrease in chl content as salinity increased resulted in lower dry weight and reduced leaf area, but this reduction in leaf area and plant height did not occur in salt-resistant canola cultivars (Kamrani et al., 2013). Proline accumulated in the roots of seedlings a salinitytolerant canola cultivar but in the shoots of a salinitysensitive cultivar (Saadia et al., 2012).

Rameeh (2012) found in eight canola genotypes that as salinity increased, potassium $\left(\mathrm{K}^{+}\right)$ion concentration decreased while the concentration of calcium $\left(\mathrm{Ca}^{2+}\right)$ and sodium $\left(\mathrm{Na}^{2+}\right)$ ions increased, reducing photosynthetic rate. This despite the fact that an increase in $\mathrm{Na}^{2+}$ and the $\mathrm{Na}^{+} / \mathrm{K}^{+}$ ratio in shoots and roots tends to occur under salt stress in a mangrove species (Parida and Das, 2005). The accumulation of $\mathrm{Na}^{2+}$ and chlorine $\left(\mathrm{Cl}^{-}\right)$ions increases osmotic potential and decreases water availability and nutrient uptake by plant roots (Acosta-Motos et al., 2017). Toxic metabolic $\mathrm{Na}^{2+}$ ions compete with $\mathrm{K}^{+}$in several major physiological processes in cells (Tester and Davenport, 2003). Therefore, electrolyte leakage, which increases in response to salinity (Mohammadreza et al., 2012), is due to increase in metabolites and concentration of ions, which is associated with an increment of $\mathrm{Cl}^{-}$and $\mathrm{Na}^{+}$entry and exclusion of $\mathrm{K}^{+}$. These resulted in a significant reduction of shoot and root dry weight, number of leaves and shoot height under salt stress (Bandeh-hagh et al., 2008). Islam et al. (2001) observed that high salt concentration in the root zone affected growth and yield in canola and mustard by upsetting water and nutritional balance. The decrease in seed yield in Brassica spp. as a result of salinity stress is due to lower stomatal conductance, nutrient uptake and photosynthesis, greater ion toxicity and an imbalance of nutrient availability (Ashraf and McNeilly, 2004).

In the leaves of five salt-stressed canola cultivars, ROSscavenging enzymes (Superoxide dismutase, SOD; catalase, CAT; Glutathione reductase; Monodehydroascorbate reductase), as well as reduced glutathione concentration were higher than in unstressed leaves (Bybordi et al., 2010c). Even though salt increased levels of MDA, hydrogen peroxide $\left(\mathrm{H}_{2} \mathrm{O}_{2}\right)$ and phenolics were observed in a salt-sensitive canola cultivar, low levels of MDA in salt-tolerant canola plants accumulate high cellular levels of $\mathrm{H}_{2} \mathrm{O}_{2}$ (Rasheed et al., 2014). In vitro plantlets grown in the presence of $\mathrm{NaCl}$ and $\mathrm{SA}$ showed increased levels of chl, carotenoids and flavonoids, proline and soluble protein (Razavizadeh, 2015).

Despite these negative effects, oilseed brassicas have wide tolerance to salt stress allowing them to adapt to a wide range of cultural, climatic and biological environments (Ashraf and McNeilly, 2004).

\section{Management strategies for canola under drought and salt stress}

\section{Management of canola under drought stress}

Hydroponics combined with the addition of AsA can improve the physiology of salt-stressed canola (Bybordi, 2012). The foliar application of antioxidants (AsA or SA, at $200 \mathrm{mg} \mathrm{I}^{-1}$ each) under various irrigation intervals impacted canola productivity by reversing the negative impact of water deficit, 
and highest seed yield was observed in a two-year study when both antioxidants were applied (EL Sabagh et al., 2017). In that study, as the distance between irrigation intervals widened, from 25 , to 35 , and then to 45 days, $\mathrm{RWC}_{\text {leaf, }}$ chl content, number of siliques per plant, seed yield, oil content and oil and protein yield decreased significantly, but the application of AsA or SA restored values, or even improved them, relative to the control. AsA at $25 \mathrm{mM}$ reduced the harmful results of $\mathrm{NaCl}$-induced oxidative stress, as observed by an increase in SOD, CAT and POX activity, and improved protein and chl content (Dolatabadian et al., 2008, 2009). SA plays a role as a non-enzymatic antioxidant in canola (Salarizdah et al., 2012) and was found to enhance the antioxidant ability of canola leaf cells and initiate new protein synthesis in the photosynthetic apparatus under drought stress, thereby improving photosynthesis (Tirani et al., 2013). SA stabilized RWC more than AsA in different deficit irrigation (soil moisture) treatments in canola (Ahmadi et al., 2015). Ullah et al. (2012) also found that application of SA and putrescine mitigated the adverse effects of drought on canola by enhancing the accumulation of soluble proteins and proline, thereby improving $\mathrm{RWC}_{\text {leaf }}$. They also noted that the applied SA and putrescine maintained the water availability of canola plants, improved the accumulation of the osmolyte proline and protected photosynthetic pigments from the adverse effects of drought stress. Moisture-stressed canola seeds that were coated with a polymer did not improve seed germination relative to control and film-coated seeds (Willenborg et al., 2004).

Physical means to alleviate salinity stress have also been used to a limited extent in canola. Mohammadi et al. (2012) exposed canola seeds to laser irradiation showed an improvement of yield and yield-related components.

\section{Management of canola under salinity stress}

Several researchers have attempted to assess the response of canola to salt stress by trying to overcome salt-induced damage via the use of proline or GB (Bandehagh et al., 2013; Dawood and Sadak, 2014), which generally positively impacts the physiology and growth of plants (Ashraf and Foolad, 2007). Bandeh-hagh et al. (2008) conducted a study with 12 canola cultivars exposed to different levels of salinity stress (125 or $250 \mathrm{mM} \mathrm{NaCl}$ ) and found that proline improved the osmotic adjustment of all cultivars as salinity level increased. At $250 \mathrm{mM}$, the contribution of $\mathrm{Na}^{+}$and proline to osmotic adjustment was 1.4- and 1.7-fold higher than at $125 \mathrm{mM}$, while GB contributed less to osmotic adjustment than proline.

Similarly, Sakr et al. (2012) conducted a field experiment to assess whether $200 \mathrm{mg} \mathrm{L}^{-1}$ proline and $400 \mathrm{mg} \mathrm{L}^{-1} \mathrm{~GB}$ could mitigate the harmful effect of soil salinity stress on canola. They found that all growth parameters, photosynthetic pigments, $\mathrm{K}$ and $\mathrm{P}$ contents decreased as salinity stress increased, but proline and GB alleviated these negative effects. The application of triacontonol, a plant growth regulator, to salt-stressed canola plants improved proline and GB levels, as well as a host of other physiological parameters (Shahbaz et al., 2013). The accumulation of compatible solutes such as proline and GB allow canola plants to maintain water balance and develop salt tolerance (Athar et al., 2009, 2015). Athar et al. (2009) found that exogenous application of $G B$ and proline at the seed germination and seedling stages ameliorated the damage effects of salt stress on canola and increased germination and seedling growth properties. They also noted that $\mathrm{GB}$ and proline protected membranes and proteins against the destabilizing effects of dehydration during abiotic stress. When Sakr and Arafa (2009) applied spermine or AsA to salinity-stressed canola plants, the content of photosynthetic pigments, $\mathrm{K}$ and $\mathrm{P}$ decreased while the content of proline, soluble sugars, $\mathrm{AsA}, \mathrm{Na}$ and $\mathrm{Cl}$ increased. Dawood and Sadak (2014) conducted a pot experiment in Egypt to study the effect of 10,15 and 20 mM GB on growth, photosynthetic pigments, osmoprotectants, antioxidant enzymes, seed yield quality and yield of canola under moderate and severe drought stress. They found that GB at all concentrations significantly increased the contents of IAA, proline, and total soluble sugars, but significantly decreased the content of MDA, $\mathrm{H}_{2} \mathrm{O}_{2}$, and antioxidant enzymes (POX, PPO, SOD, CAT, APX and NR) in canola under drought stress. Similarly, all levels of $\mathrm{GB}$ also significantly increased seed yield, oil, carbohydrate, protein, total phenolic content, tannins, and antioxidant activity of drought-stressed seeds relative to the control.

\section{Managing abiotic stresses in canola via improved agronomic practices}

Abiotic stresses can be mitigated by developing resistant/tolerance genotypes, or by developing suitable agronomic practices that can allow crops to adapt to a changing climate, such as the use of bio-regulators in cluster bean (Meena and Meena, 2017). Agronomic aspects such as adjustments to sowing time, depth, and plant density, soil manipulation through tillage practices, irrigation scheduling, soil salinity or sodicity reclamation, and plant nutrient supply with precise application of required fertilizers, can all improve crop growth and thus productivity (Hu et al., 2017). The majority of canola research that aimed to improve these aspects were to attain higher resource use efficiency, maximize farm output of economic products, improving farmers' income, and to improve and/or maintain soil health and sustainability (Shekhawat et al., 2012; Ravella et al., 2018).

\section{Conclusion}

Drought and salinity are two major abiotic stresses that can negatively affect canola growth and productivity. Sensitivity to salt in Brassica spp. is strongly dependent on the cultivar or genotype used (e.g., Su et al., 2013), each with a different salinity tolerance or threshold level, with $B$. napus and $B$. campestris classified as semi-saline-tolerant species (Miyamoto et al., 2012). A total of 34 canola accessions showed a range of sensitivities to salt stress under hydroponic conditions (Ulfat et al., 2007). Given the high heritability of yield-related traits in canola (Ali et al., 2003), selection for saltresistant varieties using traditional breeding may be a viable strategy. In canola, the salinity tolerance level of early stages of the crop is higher than later growth stages (Ashraf and McNeilly, 2004). Salinity above a threshold level reduces crop yield (Purty et al., 2008). The ideal development of suitable salt-tolerant varieties should thus be based on the salt tolerance at different developmental stages (Athar et al., 2009). Physiological and biochemical alterations in plants 
caused by both these stresses occur mainly due to lowered stomatal conductance, a decrease in chl content, limited enzyme activity, higher ROS-induced oxidative damage, and poor membrane stability, ultimately leading to a decrease in seed yield and yield-related attributes. Even so, simply by selecting cultivars that yield higher 1000-seed weight may allow for the selection of saline-tolerant canola (Rameeh et al., 2012). Some negative consequences of abiotic stresses are inevitable, but select management or breeding (Mansoori et al., 2017) strategies, such as the use of drought-resistant genotypes, adjustment of crop sowing date (Gul and Ahmad, 2007), use of mulch materials, adjusted irrigation (Gul and Ahmad, 2004), adjusted fertilization (Ahmad et al., 2007; Ebrahimian et al., 2017), and other agronomic methods (CCC, 2017b), may ensure higher productivity in canola. For example, deficit irrigation that omits watering at the flowering and seed-ripening stages will cause the greatest reductions in grain and oil yield, so if water via irrigation is to be limited, then this should not occur at these stages (Istanbulluoglu et al., 2010). The exogenous application to soil of some osmoprotectants or compatible solutes with organic amendments and essential nutrients may provide an economically viable and environmentally sound management strategy for sustainable canola production under abiotic stress in arid and semi-arid environments. When all of these agronomic options are exhausted, a range of molecular strategies to improved abiotic stress resistance in Brassica spp. exist (Zhang et al., 2014).

\section{Disclaimer}

We hereby declare that this manuscript contains no material which has been accepted for the award of any degree or diploma in any university, and that, to the best of our knowledge and belief, the manuscript contains no copy of any material previously published or written by another person except where due reference is made in the text.

\section{References}

Acosta-Motos JR, Ortuño MF, Bernal-Vicente A, Diaz-Vivancos P, Sanchez-Blanco MJ, Hernandez AJ (2017) Plant responses to salt stress: adaptive mechanisms. Agronomy 7: 18.

Aghaei K, Komatsu S (2013) Crop and medicinal plants proteomics in response to salt stress. Front Plant Sci. 4: 8.

Ahmad G, Jan A, Arif M, Jan MT, Khattak RA (2007) Influence of nitrogen and sulfur fertilization on quality of canola (Brassica napus L.) under rainfed conditions. J Zhejiang Univ Sci B 8(10): 731737.

Ahmadi M, Bahrani MJ (2009) Yield and yield components of rapeseed as influenced by water stress at different growth stages and nitrogen levels. Am Eurasian J Agric Environ Sci. 5: 755-761.

Ahmadi SAK, Ebadi A, Daneshian J, Jahanbakhsh S, Siadat SA, Tavakoli $H$ (2015) Effects of irrigation deficit and application of some growth regulators on defense mechanisms of canola. Not Bot Horti Agrobot. 43: 1-10.

Ali N, Javidfar F, Elmira JY, Mirza MY (2003) Relationship among yield components and selection criteria for yield improvement in winter rapeseed (Brassica napus L.). Pak J Bot. 35: 167-174.

Ali Q, Ashraf M (2011) Exogenously applied glycinebetaine enhances seed and seed oil quality of maize (Zea mays L.) under water deficit conditions. Env Exp Bot. 71: 249-259.

Almansouri M, Kinet JM, Lutts S (2001) Effect of salt and osmotic stresses on germination in durum wheat (Triticum durum Desf.). Plant Soil 231(2): 243-254.

Ashraf M (2009) Biotechnological approach of improving plant salt tolerance using antioxidants as markers. Biotechnol Adv. 27: 84-93.
Ashraf M, Foolad MR (2007) Roles of glycinebetaine and proline in improving plant abiotic stress resistance. Environ Exp Bot. 59: 206216.

Ashraf M, Harris P (2013) Photosynthesis under stressful environments: An overview. Photosynthetica 51: 163-190.

Ashraf M, McNeilly T (2004) Salinity tolerance in Brassica oilseeds. Crit Rev Plant Sci. 23: 157-174.

Athar HR, Ashraf M, Wahid A, Jamil A (2009) Inducing salt tolerance in canola (Brassica napus L.) by exogenous application of glycinebetaine and proline: Response at the initial growth stages. Pak J Bot. 41: 1311-1319.

Athar HR, Zafar ZU, Ashraf M (2015) Glycinebetaine improved photosynthesis in canola under salt stress: evaluation of chlorophyll fluorescence parameters as potential indicators. J Agron Crop Sci. 201: 428-442.

Bahrani A (2013) Effect of salinity on growth, ions distribution, accumulation and chlorophyll concentrations in two canola (Brassica napus L.) cultivars. Am Eurasian J Agric Env Sci. 13: 683689.

Bandeh-hagh A, Toorchi M, Mohammadi A, Chaparzadeh N, Salekdeh GH, Kazemnia H (2008) Growth and osmotic adjustment of canola genotypes in response to salinity. J Food Agric Env. 6: 201-208.

Bandehagh A, Uliaie ED, Salekdeh GH (2013) Proteomic analysis of rapeseed (Brassica napus L.) seedling roots under salt stress. Ann Biol Res. 4: 212-221.

Benlloch-González M, Quintero JM, García-Mateo MJ, Fournier JM, Benlloch M (2015) Effect of water stress and subsequent rewatering on $\mathrm{K}^{+}$and water flows in sunflower roots. A possible mechanism to tolerate water stress. Env Exp Bot. 118: 78-84.

Bézard J, Blond JP, Bernard A, Clouet P (1994) The metabolism and availability of essential fatty acids in animal and human tissues. Reprod Nutr Dev. 34: 539-568.

Bouchereau A, Besnard NC, Bensaoud A, Leport L, Renard M (1996) Water stress effects on rapeseed quality. Eur J Agron. 5: 19-30.

Bybordi A (2010a) Effects of salinity on yield and components characters in canola (Brassica napus L.) cultivars. Not Sci Biol. 2(1): 81-83.

Bybordi A (2010b) Effect of salinity and $\mathrm{N}$ sources on the activity of antioxidant enzymes in canola (Brassica napus L.). J Food Agric Env. 8: 350-353.

Bybordi A (2012) Effect of ascorbic acid and silicium on photosynthesis, antioxidant enzyme activity, and fatty acid contents in canola exposure to salt stress. J Integr Agric. 11: 16101620.

Bybordi A, Tabatabaei J (2009) Effect of salinity stress on germination and seedling properties in canola cultivars (Brassica napus L.). Not Bot Horti Agrobot. 37: 71-76.

Bybordi A, Tabatabaei SJ, Ahmadev A (2010a) Effect of salinity on the growth and peroxidase and IAA oxidase activities in canola. J Food Agric Env. 8: 109-112.

Bybordi A, Tabatabaei SJ, Ahmadev A (2010b) Effects of salinity on fatty acid composition of canola (Brassica napus L.). J Food Agric Env. 8: 113-115.

Bybordi A, Tabatabaei SJ, Ahmadev A (2010c) The influence of salinity stress on antioxidant activity in canola cultivars (Brassica napus L.). J Food Agric Env. 8: 122-127.

CCC (Canola Council of Canada). 2017a. Health benefits of canola oils. Canola Council of Canada, Manitoba, Canada. https://www.canolacouncil.org/oil-and-meal/canola-oil/healthbenefits-of-canola-oil/ (last accessed: 10 May 2018)

CCC. 2017b. Effects of soil characteristics. Canola Council of Canada, Manitoba, Canada. https://www.canolacouncil.org/canolaencyclopedia/field-characteristics/effects-of-soil-characteristics/ (last accessed: 10 May 2018)

Cartea ME, Velasco P (2008) Glucosinolates in Brassica foods: bioavailability in food and significance for human health. Phytochem Rev. 7(2): 213-229.

Chakraborty K, Sairam RK, Bhaduri D (2016) Effects of different levels of soil salinity on yield attributes, accumulation of nitrogen, and micronutrients in Brassica spp. J Plant Nutr. 39: 1026-1037. 
Chikov VI, Avvakumova NY, Bakirova GG, Belova LA, Zaripova LM (2001) Apoplastic transport of ${ }^{14} \mathrm{C}$-photosynthates measured under drought and nitrogen supply. Biol Plant. 44: 517-521.

Dawood MG, Sadak MS (2014) Physiological role of glycinebetaine in alleviating the deleterious effects of drought stress on canola plants (Brassica napus L.). Middle East J Agric Res. 3: 943-954.

de Oliveira GM, Stahl MA, Ribeiro APB, Grimaldi R, Cardoso LP, Kieckbusch TG (2015) Development of zero trans/low sat fat systems structured with sorbitan monostearate and fully hydrogenated canola oil. Eur J Lipid Sci Technol. 117: 1762-1771.

Din J, Khan SU, Ali I, Gurmani AR (2011) Physiological and agronomic response of canola varieties to drought stress.J Animal Plant Sci. 21: 78-82.

Dolatabadi N, Toorchi M (2017) Rapeseed (Brassica napus L.) genotypes response to $\mathrm{NaCl}$ salinity. J Biodiv Env Sci. 10: 265-270.

Dolatabadian A, Sanavy SAMM, Chashmi, NA (2008) The effects of foliar application of ascorbic acid (vitamin C) on antioxidant enzymes activities, lipid peroxidation and proline accumulation of canola (Brassica napus L.) under conditions of salt stress. J Agron Crop Sci. 194(3): 206-213.

Dolatabadian A, Sanavy SAMM, Sharifi M (2009) The effect of ascorbic acid on leaf feeding activity of antioxidant and proline accumulation in rapeseed (Brassica napus L.) in terms of salinity. Agric Sci Nat Resources. 13(47B): 611-621.

EL Sabagh A, Abdelaal Kh AA, Barutçular C (2017) Impact of plant originated antioxidants supplementation on growth, yield and quality traits of canola plants (Brassica napus L.) in north Nile delta under different irrigation conditions. J Exp Biol Agric Sci. 5(2): 163172.

Ebrahimian E, Bybordi A (2012) Influence of ascorbic acid foliar application on chlorophyll, flavonoids, anthocyanin and soluble sugar contents of sunflower under conditions of water deficit stress. J Food Agric Env. 10: 1026-1030.

Ebrahimian E, Bybordi A, Seyyedi SM (2017) How nitrogen and zinc levels affect seed yield, quality, and nutrient uptake of canola irrigated with saline and ultra-saline water. Commun Soil Sci Plant Anal. 48: 345-355.

El-Shaieny AHAH (2015) Seed germination percentage and early seedling establishment of five (Vigna unguiculata L. (Walp) genotypes under salt stress. Eur J Exp Biol. 5: 22-32.

Fanaei HR, Galavi M, Kafi M, Ghanbari Bonjar A (2009) Amelioration of water stress by potassium fertilizer in two oilseed species. Int J Plant Prod. 3: 41-54.

Fang Z, Bouwkamp J, Solomos T (1998) Chlorophyllase activities and chlorophyll degradation during leaf senescence in non-yellowing mutant and wild type of Phaseolus vulgaris L. J Exp Bot. 49: 503510

Food Standards Australia New Zealand (2003) Erucic Acid in Food: A Toxicological Review and Risk Assessment. Technical Report Series No. 21, $25 \quad$ pp. http://www.foodstandards.gov.au/publications/documents/Erucic \%20acid\%20monograph.pdf (last accessed: 10 May 2018)

Gan Y, Angadi SV, Cutforth HW, Potts D, Angadi VV, McDonald CL (2004) Canola and mustard response to short period of high temperature and water stress at different developmental stages. Can J Plant Sci. 84: 697-704.

Ghobadi M, Bakhshandeh M, Fathi G, Gharineh MH, Alamisaeed K, Naderi A, Ghobadi V (2006) Short and long periods of water stress during different growth stages of canola (Brassica napus L.). Effect on yield, yield components, seed oil and protein contents. J Agron. 5: 336-341.

Gibon Y, Sulpice R, Larher F (2000) Proline accumulation in canola leaf discs subjected to osmotic stress is related to the loss of chlorophylls and to the decrease of mitochondrial activity. Physiol Plant. 110: 469-476.

Gill SS, Tuteja N (2010) Reactive oxygen species and antioxidant machinery in abiotic stress tolerance in crop plants. Plant Physiol Biochem. 48: 909-930.

Gul H, Ahmad R (2004) Effect of different irrigation intervals on growth of canola (Brassica napus L.) under different salinity levels. Pak J Bot. 36: 359-372.
Gul H, Ahmad R (2007) Effect of different sowing dates on the vegetative and reproductive growth of canola (Brassica napus L.) cultivars under different salinity levels. Pak J Bot. 39: 1161-1172.

Hasegawa PM, Bressan RA, Zhu JK, Bohnert HJ (2000) Plant cellular and molecular responses to high salinity. Annu Rev Plant Physiol Plant Mol Biol. 51: 463-499.

Hassanzadeh M, Naderei M, Shiraneirad A (2005) Evaluation effects of drought stress on yield and yield components of autumn rapeseed cultivars in Isfahan. J Agric Sci. 1: 51-62.

Hawkins DJ, Kridl JC (1998) Characterization of acyl-ACP thioesterases of mangosteen (Garcinia mangostana) seed and high levels of stearate production in transgenic canola. Plant J. 13: 743752.

Hayat Q, Hayat S, Irfan M, Ahmad A (2010) Effect of exogenous salicylic acid under changing environment: A review. Env Exp Bot. 68: 14-25.

Herrera-Vásquez A, Salinas P, Holuigue L (2015) Salicylic acid and reactive oxygen species interplay in the transcriptional control of defense genes expression. Front Plant Sci. 6: 171

Horváth E, Szalai G, Janda T (2007) Induction of abiotic stress tolerance by SA signaling. J Plant Growth Regul. 26: 290-300.

Hossain A, Teixeira da Silva JA (2012) Phenology, growth and yield of three wheat (Triticum aestivum L.) varieties as affected by high temperature stress. Not Sci Biol. 4(3): 97-106.

Hossain A, Teixeira da Silva JA (2013) Wheat production in Bangladesh: its future in the light of global warming. AoB Plants 2013: pls042.

Hossain A, Teixeira da Silva JA, Lozovskaya MV, Zvolinsky VP (2012) High temperature combined with drought affect rainfed spring wheat and barley in South-Eastern Russia: I. Phenology and growth. Saudi J Biol Sci. 19: 473-487

Hu Q, Hua W, Yin Y, Zhang X, Liu L, Shi J, Zhao Y, Qin L, Chen C, Wang $H$ (2017) Rapeseed research and production in China. Crop J. 5(2): 127-135.

Hu Y, Burucs Z, Tucher SV, Schmidhalter U (2007) Short-term effects of drought and salinity on mineral nutrient distribution along growing leaves of maize seedlings. Env Exp Bot. 60: 268-275

Hu Y, Schmidhalter U (2005) Drought and salinity: A comparison of the effects of drought and salinity. J Plant Nutr Soil Sci. 168: 541549.

Hu X, Sullivan-Gilbert M, Gupta M, Thompson SA (2006) Mapping of the loci controlling oleic and linolenic acid contents and development of fad2 and fad3 allele-specific markers in canola (Brassica napus L.). Theor Appl Genet. 113: 497-507.

Islam MR, Bhuiyan MAR, Prasad B, Quddus MA (2001) Salinity effect on yield and component characters in rapeseed and mustard varieties. J Biol Sci. 1(9): 840-842.

Istanbulluoglu A, Arslan B, Gocmen E, Gezer E, Pasa C (2010) Effects of deficit irrigation regimes on the yield and growth of oilseed rape (Brassica napus L.). Biosystems Eng. 105: 388-394.

Jaleel CA, Manivannan PA, Wahid A, Farooq M, Al-Juburi HJ, Somasundaram RA, Panneerselvam R (2009) Drought stress in plants: a review on morphological characteristics and pigments composition. Int J Agric Biol. 11(1): 100-105.

Jamshidi Zinab A, Hasanloo T, Naji AM (2015) Evaluation of physiological and biochemical characteristics of four canola (Brassica napus L.) cultivars in drought condition. Iran J Field Crops Res. 13(3): 583-597 (in Farsi with English abstract).

Jensen CR, Mogensen VO, Fieldsen JK, Thage JH (1996) Seed glucosinolate, oil and protein contents of field-grown rape (Brassica napus L.) affected by soil drying and evaporative demand. Field Crops Res. 47: 93-105.

Johnston AM, Tanaka DL, Miller PR, Brandt SA, Nielsen DC, Lafond GP, Riveland NR (2002) Oilseed crops for semiarid cropping systems in the Northern Great Plains. Agron J. 94: 231-240.

Kamrani MH, Hosseinniya H, Azam RC (2013) Effect of salinity on the growth characteristics of canola (Brassica napus L.). Tech J Eng Appl Sci. 3: 2327-2333.

Kandil AA, Sharief AE, El-Mohandes SI, Keshta MM (2017) Performance of canola (Brassica napus L.) genotypes under drought stress. Int J Env Agric Biotechnol 2: 653-661. 
Knutsen HK, Alexander J, BarregAard L, Bignami M, Brüschweiler B, Ceccatelli S, Dinovi M, Edler L, Grasl-Kraupp B, Hogstrand C, Hoogenboom LR (2016). Erucic acid in feed and food. EFSA J. 14(11): 4593.

Mahajan S, Tuteja N (2005) Cold, salinity and drought stresses: An overview. Arch Biochem Biophys. 444: 139-158.

Mahmoodzadeh H (2008) Comparative study of tolerant and sensitive cultivars of Brassica napus in response to salt conditions. Asian J Plant Sci. 7: 594-598.

Malagoli P, Laine P, Rossato L, Ourry A (2005) Dynamics of nitrogen uptake and mobilization in field-grown winter oilseed rape (Brassica napus L.) from stem extension to harvest: I. Global N flows between vegetative and reproductive tissues in relation to leaf fall and their residual N. Ann Bot. 95(5): 853-861.

Mansoori I, Najafe-Zarrini H, Jelodar NB, Pakdin A (2017) Screening of canola (Brassica napus L.) genotypes for salt tolerance based on early growth stage. Biol Forum 9: 208-216.

Martiniello P, Teixeira da Silva JA (2011) Physiological and bioagronomical aspects involved in growth and yield components of cultivated forage species in Mediterranean environments: A review. Eur J Plant Sci Biotechnol 5(Special Issue 2): 64-98.

Mattioli R (2009) The proline biosynthetic genes P5CS1 and P5CS2 play overlapping roles in Arabidopsis flower transition but not in embryo development. Physiol Plant. 137: 72-85.

Meena H, Meena RS (2017) Assessment of sowing environments and bio-regulators as adaptation choice for clusterbean productivity in response to current climatic scenario. Bangladesh J Bot. 46(1): 241244.

Mittler R (2002) Oxidative stress, antioxidants and stress tolerance. Trends Plant Sci. 7(9): 405-410.

Miyamoto S, Oster MF, Rostle CT, Lenn EG (2012) Salt tolerance of oilseed crops during establishment. J Arid Land Stud. 22: 147-151.

Moaveni P, Ebrahimi A, Farahani HA (2010) Studying of oil yield variations in winter rapeseed (Brassica napus L.) cultivars under drought stress conditions. J Agric Biotechnol Sust Dev. 2:71-75.

Moghadam HRT, Zahedi H, Ghooshchi F (2011) Oil quality of canola cultivars in response to water stress and super absorbent polymer application. Pesq Agropec Trop. 41: 579-586.

Mohammadi SK, Shekari F, Fotovat R, Darudi A (2012) Effect of laser priming on canola yield and its components under salt stress. Int Agrophys. 26: 45-51.

Mohammadreza S, Amin B, Forogh A, Hossin M, Sorayya S (2012) Response of Brassica napus L grains to the interactive effect of salinity and salicylic acid. J Stress Physiol Biochem. 8: 159-166.

Morrison MJ, Stewart DW (2002) Heat stress during flowering in summer brassica. Crop Sci. 42(3): 797-803.

Mousavi SH, Vafabakhsh J, Haghighi RSA (2010) Effect of water deficit on water use efficiency of canola (Brassica napus L.) cultivars in Mashhad condition. J Agroecol 2(3): 486-491 (in Farsi with English abstract).

Namvar A, Khandan T (2015) Inoculation of rapeseed under different rates of inorganic nitrogen and sulfur fertilizer: impact on water relations, cell membrane stability, chlorophyll content and yield. Arch Agron Soil Sci. 61(8): 1137-1149.

Nasri M, Khalatbari M, Zahedi H, Paknejad F, Moghadam HRT (2008) Evaluation of micro and macro elements in drought stress condition in cultivars of rapeseed (Brassica napus L.). Amer J Agric Biol Sci. 3: 579-583.

Nazarbeygi E, Yazdi HL, Naseri R, Soleimani R (2011) The effects of different levels of salinity on proline and $a-, b-$ chlorophylls in canola. Am Eurasian J Agric Environ Sci. 10(1): 70-74.

Nelson LA, Grombacher A (1992) G92-1076 Canola Production. Historical Materials from University of NebraskaLincoln Extension, Lincoln Extension. p. 778. http://digitalcommons.unl.edu/extensionhist/778 (last accessed: 10 May 2018)

Noctor G, Foyer CH (1998) Ascorbate and glutathione: keeping active oxygen under control. Ann Review Plant Biol. 49(1): 249-279.

Nouri A, Etminan A, Teixeira da Silva JA, Mohammadi R (2011) Assessment of yield, yield related traits and drought tolerance of durum wheat genotypes (Triticum turjidum var. durum Desf.). Austr J Crop Sci. 5: 8-16.

Oertli JJ (1986) The effect of cell size on cell collapse under negative turgor pressure. J Plant Physiol. 124: 365-370.

Ozdemir O, Melike B, Tijen D, Ismail T (2004) Effects of 2,4epibrassinolide on seed germination, seedling growth, lipid peroxidation, proline content and antioxidative system of rice (Oryza sativa L.) under salinity stress. Plant Growth Regul. 42: 203211.

Parida AK, Das AB (2005) Salt tolerance and salinity effects on plants: a review. Ecotoxicol Env Safety 60: 324-349.

Paulsen GM (1994). High temperature responses of crop plants. In: Physiology and Determination of Crop Yield. Boote KJ, Bennett JM, Sinclair TR, Paulsen GM (eds). ASA, CSSA, SSSA, Madison, WI, USA. pp. 365-389.

Pignocchi C, Foyer CH (2003) Apoplastic ascorbate metabolism and its role in the regulation of cell signaling. Curr Opin Plant Biol. 6 : 379-389.

Purty RS, Kumar G, Singla-Pareek SL, Pareek A (2008) Towards salinity tolerance in Brassica: An overview. Physiol Mol Biol Plants. 14: 39-49.

Rahnema AA, Bakhshandeh AM (2006) Determination of optimum irrigation level and compatible canola varieties in the Mediterranean environment. Asian J Plant Sci. 5: 543-546.

Rameeh V (2012) lons uptake, yield and yield attributes of rapeseed exposed to salinity stress. J Soil Sci. Plant Nutr. 12: 851-861.

Rameeh V, Cherati A, Abbaszadeh F (2012) Salinity effects on yield, yield components and nutrient ions in rapeseed genotypes. J Agric Sci. 57: 19-29.

Rasheed R, Ashraf MA, Parveen S, Iqbal M, Hussain I (2014) Effect of salt stress on different growth and biochemical attributes in two canola (Brassica napus L.) cultivars. Commun Soil Sci Plant Anal. 45(5): 669-679.

Ravella R, Reddy MR, Devudigari A, Elobeid A (2018) Agronomic management practices to improve yield and oil content in winter Canola Department of Natural Resources and Environmental Design, North Carolina A\&T State University, Greensboro, NC, USA. https://scisoc.confex.com/crops/2010am/recordingredirect.cgi/id/ 9921 (last accessed: 10 May 2018).

Razavizadeh R (2015) Protein pattern of canola (Brassica napus L.) changes in response to salt and salicylic acid in vitro. Biol Lett. 52: 19-36.

Saadia M, Jamil A, Akram NA, Ashraf M (2012) A study of proline metabolism in canola (Brassica napus L.) seedlings under salt stress. Molecules 17: 5803-5815.

Sairam RK, Veerabhadra RK, Srivastava GC (2002) Differential response of wheat genotypes to long-term salinity stress in relation to oxidative stress, antioxidant activity, and osmolyte concentration. Plant Sci. 163: 1037-1046.

Sakr MT, Arafa AA (2009) Effect of some antioxidants on canola plants grown under soil salt stress condition. Pak J Biol Sci. 12: 582588.

Sakr MT, El-Sarkassy NM, Fuller MP (2012) Osmoregulators proline and glycinebetaine counteract salinity stress in canola. Agron Sust Develop. 32(3): 747-754.

Salarizdah M, Baghizadeh A, Abasi F, Mozaferi H, Salarizdah S (2012) Response of Brassica napus L. grains to the interactive effect of salinity and salicylic acid. J Stress Physiol Biochem. 8(2): 159-166.

Sánchez-Blanco MJ, Rodríguez P, Morales MA, Ortuño MF, Torrecillas A (2002) Comparative growth and water relation of Cistus albidus and Cistus monspeliensis plants during water deficit conditions and recovery. Plant Sci. 162: 107-113.

Shabani A, Sepaskhah AR, Kamgar-Haghighi AA (2013) Responses of agronomic components of rapeseed (Brassica napus L.) as influenced by deficit irrigation, water salinity and planting method. Int J Plant Prod. 7: 313-340.

Shahbaz M, Noreen N, Perveen S (2013) Triacontanol modulates photosynthesis and osmoprotectants in canola (Brassica napus L.) under saline stress. J Plant Inter. 8: 350-359. 
Shainberg I, Shalhevet J (2012) Soil Salinity Under Irrigation: Processes and Management (Vol. 51). Springer Science \& Business Media, The Netherlands.

Shalata A, Neumann PM (2001) Exogenous ascorbic acid (vitamin C) increases resistance to salt stress and reduces lipid peroxidation. J Exp Bot. 52: 2207-2211.

Sharma KD, Kuhad MS, Nandwal AS (1992) Influence of K nutrition on Brassica genotypes in response to water stress. Plant Physiol Biochem. 2: 110-115.

Sharma P, Jha AB, Dubey RS, Pessarakli M (2012) Reactive oxygen species, oxidative damage, and antioxidative defense mechanism in plants under stressful conditions. J Bot 2012: Article ID 217037: 26 pages.

Shekhawat K, Rathore SS, Premi OP, Kandpal BK, Chauhan JS (2012) Advances in agronomic management of Indian mustard (Brassica juncea (L.) Czernj. Cosson): An overview. Int J Agron. 2012, Article ID 408284: 14 pages.

Shi C-H, Xu W-D, Yu Q-R, Zhang H-Z, Yang Z-W, Wu J-G (2011) Impacts of erucic acid and glucosinolate content on genetic relationships between protein content and fatty acids of rape seed across environments. Euphytica 180: 337-346.

Shirani Rad AH, Zandi P (2012) The effect of drought stress on qualitative and quantitative traits of spring rapeseed (Brassica napus L.) cultivars. Žemdirbystè (Agric.) 99: 47-54.

Silva EC, Nogueira RJMC, Silva MA, Albuquerque MB (2011) Drought stress and plant nutrition. Plant Stress. 5 (Special Issue 1): 32-34.

Sinaki JM, Heravan EM, Rad AHS, Noormohammadi G, Zarei G (2007) The effects of water deficit during growth stages of canola (Brassica napus L.). Am Eurasian J Agric Env Sci. 4: 417-422.

Su J-J, Wu S, Xu Z-J, Qiu S, Luo T-T, Yang Y-M, Chen Q-T, Xia Y-Y, Zou S, Huang B-L, Huang B-Q (2013) Comparison of salt tolerance in brassicas and some related species. Amer J Plant Sci. 4: 1911-1917.

Sun Y-L, Hong S-K (2011) Effects of citric acid as an important component of the responses to saline and alkaline stress in the halophyte Leymus chinensis (Trin.). Plant Growth Reg. 64(2): 129139.

Suzuki N, Koussevitzky S, Mittler R, Miller G (2012) ROS and redox signalling in the response of plants to abiotic stress. Plant Cell Env. 35: 259-270.

Szabados L, Savouré A (2010) Proline: a multifunctional amino acid. Trends Plant Sci. 15(2): 89-97.

Talebi R (2009) Effective selection criteria for assessing drought stress tolerance in durum wheat (Triticum durum Desf.). J Appl Plant Physiol. 35: 64-74.

Tesfamariam EH, Annandale JG, Steyn JM (2010) Water stress effects on winter canola growth and yield. Agron J. 102(2): 658-666.

Tester M, Davenport R (2003) $\mathrm{Na}^{+}$tolerance and $\mathrm{Na}^{+}$transport in higher plants. Ann Bot. 91: 503-527.

Tirani MM, Nasibi F, Kalantari KM (2013) Interaction of salicylic acid and ethylene and their effects on some physiological and biochemical parameters in canola plants (Brassica napus L.). Photosynthetica 51: 411-418.

Tuteja N (2007) Mechanisms of high salinity tolerance in plants. Methods Enzymol. 428: 419-438.

Ulfat M, Athar HR, Ashraf M, Akram NA, Jamil A (2007) Appraisal of physiological and biochemical selection criteria for evaluation of salt tolerance in canola (Brassica napus L.). Pak J Bot. 39(5): 15931608.

Ullah F, Bano A, Nosheen A (2012) Effects of plant growth regulators on growth and oil quality of canola (Brassica napus L.) under drought stress. Pak J Bot. 44: 1873-1880.

Umar S (2006) Alleviating adverse effects of water stress on yield of sorghum, mustard and ground nut by potassium application. Pak J Bot. 38: 1373-1380.
Wang L-J, Fan L, Loescher W, Duan W, Liu G-J, Cheng J-S, Luo H-B, Li $\mathrm{S}-\mathrm{H}$ (2010) Salicylic acid alleviates decreases in photosynthesis under heat stress and accelerates recovery in grapevine leaves. BMC Plant Biol. 10: 34.

WHO (World Health Organization) (2017). World health report. www.who.int/gho/publications/world_health_statistics/2017/en/ (last accessed: 10 May 2018).

Willenborg CJ, Gulden RH, Johnson EN, Shirtliffe SJ (2004) Germination characteristics of polymer-coated canola (Brassica napus L.) seeds subjected to moisture stress at different temperatures. Agron J. 96: 786-791.

Yamaguchi T, Blumwald E (2005) Developing salt-tolerant crop plants: challenges and opportunities. Trends Plant Sci. 10: 615-620.

Zahedi H, Moghdam HRT (2011) Effect of drought stress on antioxidant enzymes activities with zeolite and selenium application in canola cultivars. Res Crops. 12: 388-392.

Zakerin HR, Shirani Rad AH, Seifzadeh S, Valadabadi SA, Mostashari Mohasses M (2014) Evaluation the effect of $\mathrm{Zn}$, Fe foliar application and variety on quality and physiological characteristics of canola (Brassica napus L.) under different ranges water deficit stress. Adv Env Biol. 8: 255-260.

Zamani Z, Nezami MT, Habibi D, Khorshidi MB (2010) Effect of quantitative and qualitative performance of four canola cultivars (Brassica napus L.) to salinity conditions. Adv Env Biol. 4: 422-427.

Zhang X, Lu G, Long W, Zou X, Li F, Nishio T (2014) Recent progress in drought and salt tolerance studies in Brassica crops. Breed Sci. 64: 60-73.

Zirgoli MH, Kahrizi D (2015) Effects of end-season drought stress on yield and yield components of rapeseed (Brassica napus L.) in warm regions of Kermanshah Province. Biharean Biologist 9(2): 133-140. 